\title{
Fc-Gamma Receptor II
}

National Cancer Institute

\section{Source}

National Cancer Institute. Fc-Gamma Receptor II. NCI Thesaurus. Code C18308.

A family of low affinity receptors for aggregates of gamma immunog lobulins (IgG).

These receptors are expressed on the surface of monocytes, macrophages,

polymorphonuclear cells, natural killer cells, T- and B-lymphocytes, and platelets. IgG

binding initiates cellular responses against foreign pathogens and soluble antigens,

induces phagocytosis of antigen-antibody complexes, and modulates antibody

production. 